Л. В. Сикало

\title{
ФРАЗЕОЛОГІЗМИ ЯК ЗАСІБ СТВОРЕННЯ КОМІЧНОГО В ХУДОЖНІХ ТЕКСТАХ (НА МАТЕРІАЛІ ТВОРІВ ДЛЯ ДІТЕЙ ПИСЬМЕННИКІВ ХІХ - ПОЧАТКУ ХХ СТОЛІТТЯ)
}

Сикало Л. В. Фразеологізми як засіб створення комічного в художніх текстах (на матеріалі творів для дітей письменників XIX - початку XX століття).

У статті розглянуто способи і прийоми використання фразеологізмів як засобу створення комічного в художніх творах для дітей.

Ключові слова: фразеологізм, мовні засоби створення комічного, естетична функція.

Сыкало Л. В. Фразеологизмы как средство создания комического в художественных текстах (на материале произведений для детей писателей XIX - начала XX века).

В статье рассмотрены способы и приемы использования фразеологизмов как средства создания комического в художественных произведениях для детей.

Ключевые слова: фразеологизм, языковые средства создания комического, эстетическая функция. 
Sykalo L. V. Phraseological units as a way of comic in the art texts (based on the works of children's writers of the XIX - early XX centuries).

The article considers the methods and techniques for using the phraseology as a means of creating a comic in works of art for children.

Key words: phraseology, language tools for creating the comic, the aesthetic function.

Прийоми створення комічного ефекту в художньому тексті $\epsilon$ об'єктом дослідження естетики, лінгвістики, літературознавства. Ці прийоми пов'язані 3 сюжетом твору, зовнішніми та внутрішніми характеристиками героїв. Як правило, комічне ототожнюють із смішним. Але таке ототожнення не виправдане, оскільки сміх виступає фізіологічним явищем і $\epsilon$ наслідком комічного. Комічне може бути засобом висміювання низького, поганого заради прекрасного, тобто воно опосередковано утверджує естетичний ідеал. Комічне $є$ інтелектуально осмисленим. Тому людина має володіти розвинутим естетичним смаком, щоб сприймати комічне. Як зазначено у стилістиці української мови «почуття гумору як різновид естетичного почуття завжди спирається на високі естетичні ідеали» [10, с. 392].

Формами прояву комічного в мистецтві є гумор, сатира, сарказм, іронія, гротеск, карикатура. У категорії комічного більше, ніж в інших категоріях естетики, знаходить своє вираження історично сформований національний ідеал та національна специфіка цінностей. Саме цим категорія комічного привертала увагу багатьох дослідників. Мовному аспекту категорії комічного присвячено роботи таких науковців, як I. Грицютенко (1972), С. Сотникова (1996), А. Попович (2001), О. Шонь (2003), Р. Семків (2004), О. Калита (2006), Т. Буйницька (2007), Л. Оліфіренко (2010). Роль фразеологічних одиниць (далі ФО) у створенні комічного вивчали В. Ужченко (1973), Б. Пришва (1977), В. Вакуров (1983), А. Павлова (2003), Л. Шимотюк (2006), Т. Шульга (2009). Мова ж творів для дітей в аспекті естетичної функції фразеологізмів як засобу створення комічного не була об'єктом вивчення. Це зумовило актуальність обраної теми.

Метою статті $\epsilon$ виявлення способів i прийомів використання фразеологізмів як засобу створення комічного у творах для дітей письменників XIX - початку XX століття. Поставлена мата передбачає вирішення таких завдань: визначити засоби створення комічного в художніх текстах; виокремити ФО в текстах творів для дітей; описати зв'язок комічного з контекстом та набуття фразеологізмом нових відтінків значення. Джерелом дослідження обрано прозові твори для дітей Г. Квітки-Основ'яненка, П. Куліша, Марка Вовчка, І. Нечуя-Левицького, Панаса Мирного, С. Воробкевича, В. Стефаника, Л. Мартовича, Г. Хоткевича, С. Васильченка, І. Липи.

Комічне (гумористичне, іронічне, сатиричне, саркастичне, гротескне) - стилістична (соціокультурна) конотація, що визначається тематикою, аксіологією, спрямованістю спілкування письменника зі своєю аудиторією через текст, зорієнтований на виявлення невідповідностей або 
ж алогічних суперечностей у реальному житті, що зумовлюють виникнення сміхового ефекту $[15$, с. 3]. М. Каган зазначає: «комічне народжується через зіткнення реального з ідеальним» [4, с. 199]. Комізм може досягатися за допомогою абсурду, двозначності, протилежності, протиріччя, ухильності, передражнюванні, незвичайному тлумаченні власних назв. Серед мовних засобів створення комічного ефекту в художньому тексті слід виділити фразеологізми, які є одним із активних емоційно-експресивних способів впливу на читача.

ФО гумористично забарвлюють текст, додаючи йому виразності, образності. Наприклад, в оповіданні П. Куліша «Орися»: Оuе ж, мабуть, $i$ сам він вийшов з води погріть старії кості на сонизі [6, с. 164]; Судженої й конем не об’̈деш! [6, с. 165]. Фразеологізми слугують створенню відповідної експресії гумору.

Для підсилення комічного ефекту письменники використовують прийом гіперболізації явищ, предметів. Наприклад, С. Воробкевич у циклі гумористичних оповідань, об'єднаних спільним заголовком «Сміховинки», уживає перебільшення, щоб описати худу тварину: Жене якийсь чоловік дорогою худобину, а худу-худу, ребра наскрізь світяться [1, с. 214]. Іронічну експресію «мудрості» мешканців міста Безглуздова автор передає за допомогою гіперболи: $A$ вони як попруть з усієї сили, а вужище як не трісне, а горіх як не свисне вгору, як не шпурне Лесем, наче галушкою, геть далеко на берег!.. [1, с. 216].

В оповіданні «Січові гості» П. Куліш уживає ФО 3 іронічним контекстом як узагальнення: П’ятнадиять разів уже виходить він на здобич, разів скільки пробивався крізь наших жовнірів; та вже тепер, здається, дамо ми йому перцю [6, с. 208]; $A$ волохи як сунулись на компутових, а тут ще й селяне побігли, куди хто втрапив, то все так змішалось, як каша, щзо вже чорт би й знайшов свою лаву: вертишся кругом, як коза у череді, та й годі!; То вже гайдамаки, почувии сеє, повісили носи $і$ записали собі пропало [7, с. 208].

Повторення фразеологізму виступає теж прийомом досягнення комічного ефекту, оскільки ФО набуває виразності й додаткових значень. Наприклад, в оповіданні І. Липи «Брехайло та Помагайло» фразеологізм посадити в холодну автор уживає три рази: Брехайла зв'язали $i$ в холодну посадили; За таке злочинство посадили Брехайла в холодну; Поки суд та діло, закувати його в колодку та й держкати в холодній [7]. ФО виступає засобом міжфразового зв'язку, посилює експресивно-стилістичний ефект.

Письменники широко вживають розмовні фразеологізми, які є одним iз основних засобів характеристики комічної ситуації, відтворення живого мовлення героїв. Панас Мирний у романі «Хіба ревуть воли, як ясла повні?», щоб наблизити читача до кола суспільно-побутових проблем уживає розмовні фразеологізми: Такий переполох - генералові на руку 
ковінька [11, с. 394]; До Стьопки -як його лизь злизав... Пропав Стьопка, як у воду впав [11, с. 408].

П. Куліш в оповіданні «Циган» за допомогою фразеологізмів 3 розмовно-згрубілим компонентом підсилює експресію іронічного образу цигана: А потім знов чаю, а потім знов ковбас та поросятини, так щуо ажс жсивіт йому обдуло! [6, с. 157]; На другий день, ще він не прочинавсь, а тут йому уже й несуть чаю, горілки, вареників, ковбас, сала - так щзо йому уже і в пельку не потовпилось! [6, с. 157]; Оторопів мій циган, розставив ноги $i$ вирячив на народ очі [6, с. 158]. I. Нечуй-Левицький в оповіданні «Баба Параска та баба Палажка» також використовує фразеологізми з розмовно-згрубілим компонентом: ... то ти не мій син, а бісів син, а твоя жінка не моя невістка, а чортова дочка [12, с. 432].

ФО біблійного походження у творах іноді набувають іронічного контексту й виконують естетичну функцію, наприклад, в оповіданні «Як безглуздівці напували горіх» із циклу «Сміховинки» С. Воробкевича: Жажндущєєо напоїти, учить святе письмо! [1, с. 215]. Фразеологізм жаждущєєго напоїми автор уживає 3 іронією. Сатиричного контексту набувають біблійні ФО в казці «Перестиглий овоч» І. Липи. Автор використовує фразеологізм дожидали як Бога з неба, щоб показати велич овоча джерела щзастя, дерева життєвих радощів та скупість індуса, який так і не зірвав достиглого овоча й не віддав народові: Цілий народ дожидав того овоча, як Бога з неба, як джерела щуастя, як початку нового життя [2, с. 585]. Щоб передати набожність баби Палажки, I. Нечуй-Левицький уводить до іï оповіді цілий ряд книжних фразеологізмів. Баба Палажка говорить про бабу Параску: Прийде раз на рік до изеркви, стане в цзвинтарі та й заглядає в церкву через поріг: мов дідько, боӥться ладану та хреста; Не святі жс з неба приходили те сало їсти: сама тріскала иілу петрівку скоромне, аж ій було завадило, ще й своїх синів годувала [12, с. 425]. Комічний ефект досягається за допомогою введених письменником лексем дідько, тріскала, які марковано зневажливістю. Іронічність підсилюється: Вже вона не одмолиться і не одхреститься: вхопить нечистий її дуиу щзе до смерті. Нехай же чорти обсмалять ї̈ на тім світі, як кабана, щуоб не брехала на мене [12, с. 426]. Чим більше автор уводить до мови Палажки книжних фразеологізмів, тим підсилюється іронічність їі характеру.

Фразеологізми, які виражають комізм у тексті представлено двома групами: 1) ФО, що характеризують персонажа; 2) фразеологізми, що характеризують відносини між персонажами.

До першої групи належать ФО, що виконують характерологічну функцію, наприклад, в оповіданні П. Куліша «Півпівника»: Куди, який ти страшний на словах! [6, с. 179]; а також в оповіданні «Гордовита пара»: Були козаки на селі против його - щео волохаті туркоти против голуба [6, с. 183]. У казці Л. Мартовича «Іван Рило» негативного іронічного 
звучання набуває фразеологізм блудна вівия - той, хто відбився від гурту, збився з правильного шляху (у моральному розумінні): $B$ 'яжуться люди в товариства.. Та й Івана беруть поміж себе. А він ходить, наче та блудна вівця [9, с.35].

Іронічності можуть набувати ФО, що виражають:

a) вади людини:

За допомогою фразеологізму П. Куліш зображує схильність до пияцтва: Був собі колись якийсь-то цуиган, та такий же то прогіркий n'яниця, щцо й не приведи господи! [6, с. 156]. Гнучкість, податливість чоловічої натури Омелька в оповіданні «Баба Параска та баба Палажка» I. Нечуй-Левицький передав ФО, ужитими в мові Параски: Ще, на біду, й чоловік мій, Омелько, вдався вже геть-то гнучкий, як батіг з клоччя [12, с. 414]; Мій Омелько й собі раденький, мцо дурненький, та все до неї через тин: $2 i, 2 i$, $2 i$ ! [12, с. 422]. Дурнуватість Омелька письменник передає фразеологізмами, ужитими в мові Палажки: $Я$ одіслала 3 гарбузом двадиять пар старостів, а до неї ніхто з старостами $і$ через поріг не заглядав, доки не піддурила Омелька; та й той узяв ї̈, мабуть, через те, щзо в його й тепер не всі вдома, а ззамолоду зовсім-таки не було однієї клепки в голові [12, с. 426].

б) статус, спосіб життя:

Через ФО гуло в кишені П. Куліш передає бідність короля в оповіданні «Січові стрільці»: А в короля і в самого гуло в кишені, бо тоді вік був такий на королів та на панів, щзо у всіх кишені попродирались [6, с. 206]; Марко Вовчок у творі «Сестра» вживає іронічне порівняння Такі стали голі, як турецькі святі [8, с. 49]. Наведені фразеологізми характеризують украй збіднілу людину. Іронічно-сатиричного контексту набувають ФО, побудовані на протиставленні способу життя головних персонажів думиказки С. Васильченка «Ось та Ась»: Живе москаль Ась, як сир у маслі катається, в Осевому добрі купається; хата у козака гарна, біла, а жінка молодая, мила [3, с. 147]; Тоді козак Ось присягу пам'ятає, голий $і$ босий із своєї хати в дорогу рушає; Босий по дорозі, голий на морозі... [3, с. 148]. В оповіданні В.Стефаника «Злодій» саркастичного забарвлення набуває фразеологізм біленька кістка - іронічне визначення великого панства, аристократії: Походи трохи по нім... та ц̌ готовий, ребра потерті на форост, бо то біленька кістка, як папір [13, с. 21]. Саркастичності висловлюванню надає також ФО не нагинатися низько, ужита у казці Г. Хоткевича для молодшого шкільного віку «Чи можна грошима загатити річку?»: А трудно йому нагинатися: одно те, щзо ніколи не нагинався так низько, все інші за нього нагиналися... [14, с. 12].

в) зовнішній вигляд персонажа:

Фразеологізми для підсилення комічного ефекту вживає П. Куліш в оповіданні «Циган»: Поб'ють йому усю пику, попідставляють окуляри [6, 
c. 156]. Через опис одягу в оповіданні «Орися» автор іронічно показує заможність персонажа: Увесь у кармазині, а з пояса золото ажк капає [6, с. 163]. За допомогою нанизування фразеологізмів I. Нечуй-Левицький в оповіданні «Баба Параска та Баба Палажка» досягає градації, даючи портретну характеристику дячихи: Яка погана наша дячиха! Я вродилась $\boldsymbol{i}$ охрестилась, а такої поганої не бачила! Вже баба Солов'їха багато крамуа од неї, хоч і в Солов'їхи ніс, як за сім гривень сокира. А дячиха ж чорна-чорна, хоч чіпляй на спину веретена та решета та садови в циганське шатро; ніс, як ключка; очі витрішкуваті, як у сови; брови, як пацюки; як говорить, то сопе, наче ковальський міх, а морда неначе сажею обмазана [12, с. 422]. Ужиті автором фразеологізми гіперболізовано передають риси позначуваних реалій через призму комічного.

До другої групи відносимо ФО, які ілюструють відповідне відношення до дійової особи або явища через опозиції автор - персонаж, персонаж- персонаж. Це може бути добродушна насмішка, удаване вихваляння, прихована іронія.

За допомогою фразеологізмів С. Воробкевич у циклі гумористичних оповідань «Сміховинки» поєднує естетичні категорії іронічного та сатиричного. Наприклад, протилежність фразеологізму прямому значенню слів ілюструє ФО розуму насипано в голову лопатою [1, с. 213], що характеризує тупість усіх мешканців міста Безглуздова: Кождий чоловік був там дуже-дуже мудрий. Казали, що кождому безглуздівиеві розуму насипано в голову лопатою, що безглуздівиі поӥли всі розуми иього світа [1, с. 213]. Автор створює удавану позитивну оцінку мешканців міста: $3 i$ всіх усюдів заходили до них люди позичати розум, як у лихваря грошей [1, с. 213]; висміює «мудрих» жителів: 3 того горіха, мабуть, безглуздівиі наӥлися такої мудрості, бо як настане тільки осінь, то всі довкола нього $і$ днюють $i$ ночують та товчуть горіхи [1, с. 215]. Іронія набуває дошкульної насмішки з Яремка Головатого, начальника Безглуздова: Лиш один не мав жадної хиби: Яремко Головатий, чільна $і$ справді дуже головата людина [1, с. 213]; I коли людям оповів про свою мандрівку і про свою пригоду, то всі його величали, прозивали головачем, бо пізнали, щзо він ополоник міжс ложккам [1, с. 215]; Пора і Яремкові вертати додому, бо ж дома без нього як без рук [1, с. 217].

Глузливо-іронічну функцію фразеологізми частіше виконують у висловлюваннях, які адресовано комічному персонажеві. Вони містять осуд, зневажливу оцінку. Наприклад, в оповіданні . Нечуя-Левицького «Баба Параска та Баба Палажка» сусідки дають одна одній в’їдливу сатиричну характеристику. У мові баби Параски письменник використовує ФО: Але ніхто мені так не допік аж до живих печінок, як та капосна баба Палажка Солов'їха [12, с. 414]; Як говорить, то тільки плюе словами... [12, с. 415]; Коли б я пак була хоч трохи зла, хоч на десяту 
частку мала такі залізні зуби, як у Соловїхи, може б я ще й одбилась та одгризлась од неї! [12, с. 421]; Бо знала, щуо вона рознесе зараз по селі, як сорока на хвості; Om виріс язик у роті - довший, ніюс у корови! $[12$, c. 423]. У мові баби Палажки вжиті автором такі фразеологізми: Нема мені де сховатись од неї, як од мух у спасівку, хоч лягай у домовину [12, с. 427]; Біжить проклята, прудка, як коза, а порожні відра цуок та цүок об коромисло [12, с. 429]; Говорю я до неї, а в душі в мене тьохкає, бо я бачила, щуо Параска була в волості, а де вона помаже язиком, там і святі образи не помож⿻мв [12, с. 430]. Репліки персонажів витримані в стилі розмов «язикатої сільської баби», фразеологізми підсилюють образність.

В оповіданні «Малоросійська биль» Г. Квітка-Основ’яненко за допомогою ФО передає зневажливість батька Демка до дяків: Чи задаси пинхви нашим дякам? [5, с. 409]; Мудруйтесь, мудруйтесь! Сьогодні ваше пущуання; забудете бришкати [5, с. 411]. Батько вірить, що син баки заб' [5, с. 411] дякам; заткнемо їх за пояс; носа їм утерти, щзоб не дуже брови піднімали! [5, с. 408]. Іронія підсилюється контекстом, який характеризується категорично негативною оцінкою, експресія образу зростає.

Дотепності висловлюванню надають фразеологізми, що містять приховану іронію, коли персонаж запевняє у своїй правдивості, переконуючи інших. П. Куліш в оповіданні «Циган» розкриваючи нові семантичні поля художнього образу цигана використовує ФО: Коли я сюди зайшов красти, або чого другого, то от чорна земля, щцб я іще почорнів! Щоб мені і руки й ноги повсихали! Щоб я зараз сказився! Щоб світу божюго не побачив, коли я знаю, де я, $i$ щуо, $i$ куди оце я зайшов!.. [6, с. 157]. . Липа в оповіданні «Брехайло та Помагайло» також використовує ФО, коли персонаж запевняє у своїй «чесності»: $A$ om як колись я йшов по Москві, так бачив своїми очима - бодай мені повилазили, коли брешу - бачив, як семеро чоловік плавало по річці на одному редьквяному листі. Коли брешу, подумаєте, то нехай мені язик усохне; А ось як ішов я по Москві одного разу, то бодай мені руки й ноги відсохли, коли брешу, бачив, як півень тягав у зубах півмісяия [7]. Так автор сатирично висмією ваду людини - брехливість.

Отже, фразеологізми є важливим мовним засобом вираження комічного у творах для дітей письменників XIX - початку XX століття. Їх використання зумовлене специфічними ідейно-художніми настановами митців та особливостями художньої майстерності. Аналіз показав, що для досягнення комічного ефекту письменники вдаються до гіперболізації, узагальнення, повторення, уведення в художній текст ФО інших стилів. Ці особливості мають збудити в читача сміх, в одних випадках злий, а в інших - радісний. Ми виявили, що література для дітей XIX - початку XX століття містить гостроту висміювання вад людини та суспільного устрою, що $є$ характерною особливістю усього періоду української літератури 


\section{XIX - початку XX століття. Перспективу подальшого дослідження вбачаємо в детальному вивченні естетичної функції фразеологізмів у художніх творах для дітей зазначеного періоду.}

\section{Література}

1. Воробкевич С. Сміховинки // Українська дитяча література : хрестоматія : у 2-х ч. : [навч. посіб.] / упоряд. : І. А. Луценко, А. М. Подолинний, Б. Й. Чайковський. - К., 1992. - Ч. 1. - С. 213-220.

2. Дивосвіт «Веселки» : антол. л-ри для дітей та юнацтва : у 3-х т. / упоряд. та бібліогр. довідки Б. Й. Чайковського та ін. - К. : Веселка, 2004. - Т. 1. Українська література. - 2004. - 631 с.

3. Живиця : хрестоматія укр. л-ри ХХ ст. : у 2-х кн. / упоряд. М. М. Конончук, Н. І. Бондар, Т. І. Конончук ; за ред. М. М. Конончука. - К. : Твім Інтер, 1998. - Кн. 1. - 1998. - 720 с.

4. Каган М. С. Лекции по марксистско-ленинской эстетике / М. С. Каган. - [2-е изд., расшир. и перераб.]. - Л. : Изд-во Ленингр. ун-та, 1971. - Гл. 8. Возвышенное и низменное : сущность комического и его основные формы. - С. 199-211.

5. Квітка-Основяненко Г. Ф. Малоросійська биль / Г. Ф. Квітка-Основяненко // КвіткаОсновяненко Г. Ф. Зібрання творів : у 7-и т. - К., 1981. - Т. 3 : Прозові твори / упоряд. і прим. М. С. Грицюти. - К., 1981. - С. 407-413.

6. Куліш П. Твори : у 2-х т. / П. Куліш. - К. : Дніпро, 1989. - Т. 2. : Чорна рада : хроніка 1663 року ; Оповідання ; Драматичні твори ; Статті та рецензії [підгот. тексти, упоряд. і склав приміт. М. Л. Гончарук]. - 586 с.

7. Липа I. Брехайло та Помогайло [Електронний ресурс] / Іван Липа. - Режим доступу : http://abetka.ukrlife.org/b\&p.htm

8. Марко Вовчок. Сестра // Вовчок Марко. Твори : у 3-х т. - К., 1975. - Т. 1: Повісті та оповідання. - С. 33-52.

9. Мартович Л. С. Винайдений рукопис про руський край : [оповідання для серед. та старшого шк. віку] / Лесь Мартович [упоряд., передм. та прим. О. Д. Гнідан ; худож. П. Х. Ткаченко]. - К. : Веселка, 1991. - $206 \mathrm{c}$.

10. Мацько Л. І. Стилістика української мови : [підручник] / Мацько Л. І., Сидоренко О. М., Мацько О. М. - К. : Вища шк., 2003. - 462 с.

11. Мирний П. Хіба ревуть воли, як ясла повні? / Панас Мирний // Мирний П. Твори : у 2-х т. - К. : Наук. думка, 1989. - Т. 1. : Оповідання. Повісті. Роман. Драматичні твори. (1872-1898) / [упоряд. і прим. М. Л. Гончарука ; авт. вступ. ст. і ред. П. П. Хропко]. - 1989. - 757 с.

12. Нечуй-Левицький І. С. Твори : у 2-х т. / І. С. Нечуй-Левицький. - К. : Наук. думка, 1985. - Т. 1 : Повісті та оповідання. П'єса. - 1985. - 638 с.

13. Стефаник В. Вибрані твори / В. Стефаник. - Х. : Ранок, 2003. - 192 с.

14. Хоткевич Г. Чи можна грошима загатити річку? : казка : [для мол. шк. віку] / Гнат Хоткевич. К.: Веселка, 1991. - 16 с.

15. Шульга Т. А. Гумористичний компонент у семантиці лексичних і фразеологічних одиниць мови творів Свгена Дударя : автореф. дис. на здобуття наук. ступеня канд. філол. наук : спец. 10.02.01 «Українська мова»/ Т. А. Шульга. - К., 2009. - 20 с. 